\title{
Nowhere Home: The Waiting of Vulnerable Child Refugees
}

\section{Odin Lysaker}

\section{INTRODUCTION}

In her 2012 documentary Nowhere Home, filmmaker Margreth Olin sheds light on the vulnerabilities of child migrants subjected to prolonged waiting. The documentary shows unaccompanied minors being offered only temporary residence. Echoing the UNHCR's vocabulary, Olin illustrates why these irregular migrants can be characterized as 'particularly vulnerable'. However, the nature of vulnerability is contested. In the following, I therefore ask what is an adequate understanding of the concept of vulnerability.

Due to child refugees' particular vulnerability, prolonged waiting can violate their bodily health and life quality, as well as their inherent dignity and human rights. Within the context of moral philosophy, I introduce what I term a waiting guarantee. This principle sets an ethical threshold level regarding the violation of child refugees' vulnerability. Furthermore, it stresses the impacts of child refugees' prolonged waiting. Consequently,

O. Lysaker $(\bowtie)$

University of Agder, Kristiansand, Norway

e-mail: odin.lysaker@uia.no

(C) The Author(s) 2020

A. M. Dancus et al. (eds.),

Vulnerability in Scandinavian Art and Culture, https://doi.org/10.1007/978-3-030-37382-5_5 
the principle states that it is morally unacceptable if prolonged waiting puts child refugees' childhood on hold. Illustrated through minors' life histories in Olin's documentary, I claim that we should approach the issue of child refugees' long-term waiting through the lens of the waiting guarantee. Thus, vulnerability is accounted as something enabling.

I begin by defining the concept of vulnerability as grounded in humans' existential precondition against the horizon of Martha A. Fineman and other feminist outlooks. Then, inspired by Hannah Arendt, I shed light on the implications of falling out of time concerning time as a normative resource and a scarce good. To conclude, drawing on Martha C. Nussbaum, I present the waiting guarantee.

\section{Vulnerability as a Human Condition}

In Nowhere Home, Olin mirrors the UNHCR, since the child migrants depicted in her documentary can be described as particularly vulnerable. Vulnerability is a key concept within migration discourse (Crock and Bhabha 2007, p. 22; Bhabha 2016, p. 22; Silas 2018, p. 178; Kulu-Glasgow et al. 2019). Nonetheless, this concept is disputed. I suggest that we perceive vulnerability as an embodied human condition.

\section{Child Refugees-The 'Most Vulnevable'}

The UNHCR ascribes vulnerability to different groups, such as refugees, stateless people and asylum seekers, who are viewed as the 'most vulnerable groups [...] in the world' (UNHCR 2016, my italics). However, 'within this group, there are people who are even more vulnerable'; for instance, children, the elderly, disabled and ill people (UNHCR 2016, my italics). Legally, in accordance with the UN 1989 Child Convention, all humans under 18 years old are recognized as children. The UNHCR claims that child refugees in terms of unaccompanied children are 'particularly vulnerable' (UNHCR 1998, my italics), based on the fact that unaccompanied minors are often separated from their parents, guardians, or caregivers (UNHCR 1999). The younger these children are (i.e. 6-9 years of age), the more vulnerable they become if they suffer from traumatic experiences (Sourander 1998).

The UN 1951 Refugee Convention and its 1967 Protocol also count refugees as some of 'the most vulnerable people in the world' (UNHCR 1951, my italics). This is due to refugees' 'well-founded fear of being 
persecuted' by their own country. Such vulnerability exposes them to mis-recognition of their identities based on, inter alia, race, religion and nationality, as well as political and social membership. This violates refugees' human dignity, since the UN 1951 Refugee Convention is grounded in the UN 1948 Universal Human Rights Declaration, chiefly Article 14, which is based on the moral idea of the 'recognition of the inherent dignity' stated in both the Preamble and Article 1. Humans' dignity is the moral heart of human rights (Habermas 2010). Therefore, refugees' vulnerability in general, and child refugees' special vulnerability in particular, should be morally protected through recognizing their dignity.

\section{Refugee Patients}

'I had enough of this life', Husein tells Olin. He and his brother Hassan, both minors that have fled Afghanistan, have struggled for years to make the Norwegian government recognize Husein's very poor health situation. In fact, Husein can be described as a refugee patient, since he feels like he '[j] ust [has] to wait all the time, and never gain control of [his] life because of what [he has] experienced'.

Within the migration discourse, the term 'refugee patient' comprises at least three aspects (Varvin 2008). First, refugee patients' human dignity and human rights are violated due to, for instance, torture and sexual abuse (Sourander 1998).

Second, refugee patients experience various forms of loss, such as loss of parents or other caregivers; loss of a place of belonging; or loss of mental and physical capabilities due to, for example, traumatization and posttraumatic stress disorder (PTSD). Refugee patients are sometimes already suffering from pre-migration traumatic experiences (e.g. forced to hide, beatings, torture, imprisonment and lack of water or food). Moreover, traumas can appear during the flight (e.g. loss of hope and prospects of a good life, uncertainty and mental pain). Moreover, refugee patients can suffer from stressors in the sense of post-migration traumas (e.g. ongoing temporary protection, anxiety, fear of being repatriated, poor access to health care, delays in processing applications, loneliness, boredom, depression, isolation and suicide, as well as worries about their family at home, disqualification from work, financial difficulties, loss of identity, competence and social roles) (Carswell et al. 2009; Miller and Rasmussen 2010; Li et al. 2016). Such post-migration problems can be related to 
'adverse childhood experience'. Children may experience negative events during their upbringing, which are traumatizing due to the children being exposed to severe events both inside and outside the family (e.g. loss of caregivers in early childhood, or being physically, sexually, emotionally, or verbally abused by caregivers) (Cassidy and Mohr 2001). Additionally, by affecting the mental health and life quality of particularly vulnerable child refugees, adverse childhood experiences can influence, and even affect, their lifespan (Anda et al. 2006). The latter is important in light of the consequences regarding child refugees having their childhood put on hold. These kinds of experiences of traumas before, during and/or after the flight reduce the child refugees' functioning and coping with their own vulnerability (Jensen et al. 2015). Even so, such trauma may cause problems regarding the child refugees' later capacity for development throughout their life course. Thus, recognition as love, respect and esteem, as well as persons' basic need for positive self-development concerning self-confidence, self-respect and self-esteem, are at stake (Honneth 1995). As a result, refugee patients often experience both multiple and prolonged traumatic events. This kind of trauma undermines their bodily (i.e. mental and physical) health.

Third, refugee patients are characterized by resilience in connection to being capable of living through, as well as tackling, various kinds of major stress over a longer time period of prolonged waiting, even though they are suffering from traumas (Varvin 2008; Fazel et al. 2012). Stable environments within which the refugee patient can be offered treatment, rehabilitation and development must be created (Varvin 2008). Consequently, the particularly vulnerable group of minor refugee patients should be recognized so as to develop the capacity to reflect on and relate to their own experiences, emotions and thoughts. Resilience also concerns re-establishing and cultivating close and stable relationships based on basic mutual recognition, such as love and care (ibid.; Honneth 1995). Here, positive effects can be achieved concerning their bodily health if they receive a permanent residence permit (Silove et al. 2007). However, many refugees are subjected to long-term waiting for the result of the government's process, which may take months, years, or sometimes even decades (Jakobsen et al. 2017, p. 2; Parekh 2017). 


\section{Vulnerability as an Existential Precondition}

It is worth conceiving the concept of 'particularly vulnerable' child refugees in light of the philosophical discourse about vulnerability. Roughly, vulnerability can be accounted for in two ways (Mackenzie et al. 2014 , pp. 4-7; Mackenzie 2017, p. 85). First, vulnerability is considered as 'the contingent and relational susceptibility of particular persons or groups to threats to their interests'. Second, vulnerability refers to 'the universal capacity to suffer', which is 'inherent to human embodiment' (Mackenzie 2017, p. 85; see Fineman 2008, p. 9; Mackenzie et al. 2014, pp. 1-2, 4, 7; Ferrarese 2017, p. 77).

Surely, between these two outlooks, it can be argued that the former is the more relevant to child refugees, since this interest-based vulnerability' is sensitive to contingent contexts within which some members of this group have a 'diminished capacity to safeguard their interests relative to others' while being subjected to, inter alia, prolonged waiting. The group of particularly vulnerable child refugees is 'especially susceptible to wrongful harms', which are due to various inequalities (e.g. resources and power) (Mackenzie 2017, p. 85).

However, morally speaking, I adopt the latter 'suffering-based vulnerability', which more adequately captures the situation of child refugees potentially becoming refugee patients. Here, traumatization, for example, requires focusing more on bodily experiences, including the subjective suffering of child refugees exposed to prolonged waiting. Equally, to highlight the life histories in Olin's documentary, the 'suffering-based vulnerability' is more relevant, since these minor migrants biographically reveal experiencing bodily harms (e.g. traumatization).

Such vulnerability is ontological; namely, grounded in certain existential preconditions (Nussbaum 2006, p. 160; Fineman 2008, pp. 1-2, fn. 25 at 9, 12; 2010, p. 28; Lysaker 2013; Mackenzie 2014, pp. 33, 34, 36, 38; Mackenzie et al. 2014, pp. 1-2, 4, 7; Ferrarese 2018, pp. 27-29). Thus, vulnerability is situated in 'a universal, inevitable, enduring aspect of the human condition' (Fineman 2008, pp. 1, 8; see 1, 12; Mackenzie et al. 2014, pp. 4, 5, 8). Put differently, vulnerability is a '[g]eneral shared feature [...] of human life' (Nussbaum 2013, p. 401, my italics; see Nussbaum 2006, pp. 43, 87-88, 160, 221, 237, 278). Subsequently, it is something non-optional and thus irremovable (Lysaker 2013), which means that, as bodily beings, humans 'cannot nor would $[. .$.$] want to$ 
fully eradicate our vulnerability to others' (Petherbridge 2016, p. 598, my italics).

Humans' vulnerability is also related to 'two forms of individual differences'. First, vulnerability is linked to 'physical' variations (e.g. mental, emotional, sensual, intellectual and other contrasts in human embodiment). Such variations can be further linked to the fact that '[all] [h] uman beings are in general disabled' (Nussbaum 2004, p. 306, my italics). This implies different ways in which each human being is 'mortal, weak-eyed, weak-kneed, with terrible backs and necks, short memories and so forth' (ibid.). Such 'general disability' can be viewed in light of what I term humans' 'existential life graph' (Lysaker 2015; see Mackenzie et al. 2014, p. 1; Ferrarese 2018 , p. 33). Our lives always already fluctuate, by which I mean that throughout one's life course humans' shared vulnerability can occur to a lesser or greater extent, as well as for a shorter or longer period of time (Nussbaum 2006, p. 101).

Second, our vulnerability is connected to 'social' variations (e.g. constructed on the basis that individuals are institutionally situated within the context of complex and overlapping webs of relationships) (Fineman 2013 , p. 21). Then, vulnerability is contingent on the social environment within which the person exists, such as birth, upbringing, development, adulthood and illness (Nussbaum 2006, pp. 87, 111, 120, 125, 129, 132, $143,160,221)$. However, contextually, vulnerability also signifies something non-contingent, such as ageing, health reduction, protracted illness, old age and one's own death (ibid., pp. 111, 120, 123, 125, 143). In turn, this 'requires forms of social action and cooperation' through recognition as love, respect and esteem (Honneth 1995; Anderson and Honneth 2005; Petherbridge 2016, p. 598) to have this social dimension surrounding one's vulnerability safeguarded.

Vulnerability is further grounded in basic needs (e.g. food, water, health, sanitation, shelter, clothing and education) (Fineman 2008, p. 10; Mackenzie et al. 2014, p. 1; Ferrarese 2017, p. 77). These bodily needs are extended through all periods of a person's life course. To exist at all, as well as to develop our life in accordance with our capabilities, these needs must be met. If not, due to our vulnerability, we may be exposed to various forms of suffering; for example, physical illness, injury and mortality (Mackenzie et al. 2014, p. 1). Thus, in light of vulnerability creating basic needs, we should, as needy and suffering creatures, be provided with capabilities for developing an undistorted and positive self-relation (Honneth 1995; Petherbridge 2016, p. 598; Schweiger and Graf 2017, p. 245). 
Our bodily vulnerability, as based on humans' fundamental needs, creates 'a [basic] form of interdependence that attends to the subject in her [bodily] needfulness' (Petherbridge 2016, p. 598; see Fineman 2010, pp. 21-22; Mackenzie et al. 2014, p. 1). This dependency is 'unavoidable and inevitable', as well as 'developmental and biological' (ibid., p. 23). Irrespective of age, it makes us needy vis-à-vis others (Honneth 1995; Mackenzie et al. 2014, pp. 1, 4; Ferrarese 2017, p. 77). Still, such dependency is 'episodic and as shifting in degree over the lifetime of an individual' (Fineman 2008, p. 12; 2010, p. 25).

Vulnerability is also connected to human affections. We are emotionally and psychologically vulnerable to others (e.g. loss, mourning and grief) (Mackenzie et al. 2014, pp. 1, 7). Building on this, humans' fundamental 'openness' vis-à-vis the 'richness of sensuality and sensual encounters with [oneself] the other and with the world' (Petherbridge 2016, p. 598).

It is significant, therefore, to disconnect vulnerability from such negative associations as helplessness and passivity (Mackenzie 2014, p. 33; Fineman 2008 , p. 8 ). Rather, we should recognize that vulnerability contains a productive potentiality; namely, that 'vulnerability can have positive manifestations and value, enabling the development of empathy, compassion, and community' (Gilson 2013, p. 8, my italics; see Fineman 2008, p. 11; Petherbridge 2016, p. 598; Ferrarese 2018, p. 30). In turn, our vulnerability enables humans to act and interact (Ferrarese 2018, p. 30) in terms of 'affective activity' (Ferrarese 2018, p. 38). This is related to 'relational autonomy' (Mackenzie 2014, p. 33; Ferrarese 2018, p. 30). Such an approach to autonomy is 'premised on recognition of human vulnerability' (Mackenzie et al. 2014, p. 16). Here, the so-called 'autonomy myth'-namely, the imaginary that humans are self-sufficient, independent, and rational (Fineman 2008; Mackenzie 2014, p. 33) -is criticized.

In view of suffering-based vulnerability, then, the UNHCR's as well as Olin's description of child refugees as particularly vulnerable relates to a basic, inherent and bodily vulnerability, shared universally and expressed uniquely by all humans.

\section{Vulnerable to Moral Injury}

Ethically, child refugees' particular vulnerability can be conceptualized in view of being 'vulnerable to moral injury' (Honneth 1995, p 48; see Butler 2004, p. 20). Specifically, it is an affinity between one's subjective experience of embodied vulnerability, on the one hand, and human 
dignity, on the other. When individuals mutually perceive each other as 'morally vulnerable persons', they recognize each other concerning their 'fundamental claims to [bodily] integrity' (Honneth 1995, p. 48). Consequently, 'the specific vulnerability of humans result[s] from the internal interdependence [grounded in] [...] recognition' (ibid., p. 131, my italics). Thus, each person shares a basic need for recognition, which is due to our specific embodied vulnerability that can be exposed to 'injury' through others' mis-recognition (ibid.; see Butler 2004, p. 20; 2010, p. 2). If so, to have one's bodily vulnerability injured can 'bring the identity of the person as a whole to the point of collapse' (ibid., p. 132, my italics; see pp. 133, 135).

In the case of child refugees, being vulnerable to moral injury indicates having one's particular vulnerability mis-recognized in the shape of violations of the person's bodily integrity and human dignity. Accordingly, child refugees' development through a wide range of processes consisting of socialization, internalization and individuation ideally leads to an undistorted and positive self-realization: 'Without the assumption of a certain measure of self-confidence, of legally enshrined autonomy and of a belief in one's ability, it is impossible to imagine a successful process of self-realization' (Honneth 2001, p. 50, my italics). Such mutual relationships of recognition as love, respect and esteem are necessary components, therefore, if children, hereunder child refugees, are to achieve a successful self-realization. If not, they would suffer from misdevelopment: '[I]n order to be able to acquire an undistorted relation-to-self, human subjects always need-over and above the experience of affectionate care and legal recognition-a form of social esteem that allows them to relate positively to their concrete traits and abilities' (Honneth 1995, p. 121, my italics). Here, humans' basic undistorted self-relations include self-confidence, self-respect and self-esteem. These dimensions represent ways to safeguard that humans, including child refugees, to the greatest extent possible, are capable of relating to themselves, to others, as well as to the wider world in an undistorted, positive and successful manner.

It is thus important to avoid 'autonomy gaps' (Anderson 2017); namely, the discrepancy between a cultural expectation that people, on a societal and institutional level, become autonomous, on the one hand, and what I above term as humans' 'existential life graph', on the other. Autonomy gaps are thus undermined, by, for instance, harming individuals with respect to their actual capabilities for societal participation on a par with each other. Moreover, such autonomy gaps cause emotional 
harm because of the bodily stress people experience due to powerlessness, while not being able to continue with the expectations of being autonomous.

Therefore, since human dignity is ontologically grounded in our bodily vulnerability, autonomy gaps can even degrade human dignity. In turn, it is important to supplement our story about humans as autonomous by showing the ways in which we are vulnerable and dependent. To the extent to which child refugees are often more vulnerable than others, they are also more exposed to these autonomy gaps and ways in which could result in mis-recognition of their dignity.

However, through recognition children develop skills to tackle their embodied vulnerability and injurability on the basis of 'agentic resources' (Anderson 2017). Through such developmental capacities and processes, children undergo a transition from being totally dependent on others (e.g. their parents) to learning how to become increasingly mature and independent. Hence, children and their childhoods are 'never on hold', since 'developmental needs do not wait for an emergency phase of a refugee situation to end' (Sourander 1998, my italics; see Graf and Schweiger 2017; Schweiger and Graf 2017). Still, traumas before, during and/or after they flee can 'harm children's physical, intellectual, psychological, cultural and social development' (Sourander 1998), which is due to disruption, uprooting and insecurity of forced displacement and prolonged waiting. Against this horizon, vulnerability is 'inherent' by being ontologically conditioned through embodied developmental capabilities, as well as 'situational' by being practised as well as hindered within concrete life forms (Mackenzie 2017, p. 89).

In light of the significant role of recognition concerning child refugees' particular vulnerability, mis-recognition can incorporate structural 'patterns of humiliation and denigration' (Anderson and Honneth 2005, pp. 135-136). Subsequently, this makes children 'less able to be self-determining' concerning the care for undistorted and negative self-realization related to their agentic resources in a developmental life stage that are crucial for every child (ibid., pp. 135-136; Anderson 2017; Schweiger and Graf 2017, p. 247). 


\section{Falling Out of Time}

'Are you lonely?', Olin asks Goli, a Kurdish migrant minor, who was recently deported from Norway. 'Yes', he answers. Then Goli adds: 'Sometimes I don't give a fuck, but not always.' In Olin's documentary, Goli's everyday life can be described as falling out of time, since he is sent back and forth between Norway and Greece.

Due to protracted refugee situations and other forms of prolonged waiting, particularly vulnerable child refugees and other migration minors are mis-recognized if they fall out of time. This means an exclusion from a normal, expectable lifecycle in terms of socially shared scripts of life pathways and life courses, including expectations about the timing and sequencing of role transitions (Settersten and Hagestad 1996; Hagestad and Dykstra 2016). Subsequently, refugee minors' life course is put on hold regarding temporally conditioned everyday life practices of childhood (e.g. eating, being cared for, playing, or attending school). Furthermore, falling out of time implies that normal expectancies about a healthy body, predictable linear time and expected durations are no longer conformed to the normal timetable scripts (Hagestad 1996).

\section{Protracted Refugee Situations}

'Nobody wants to do die, but I risk it. I have waited too long', Goli answers in response to Olin expressing her worry when he is about to travel in a boat bringing irregular migrants to Europe. Olin continues by saying that '[ $t]$ here's a possibility of it's not going to be $[\ldots]$ a suicide trip'.

By introducing the concept of protracted refugee situations, the UNHCR seeks durable solutions to the current global challenge of forced displacement, such as in Goli's case. The term is defined as a situation in which refugees, including children, find themselves in a 'long-lasting and intractable state of limbo' (UNHCR 2004, my italics). Moreover, the term is defined as situations lasting at least 5 years, with no prospects of durable solutions. However, according to the UNHCR's figures, globally many protracted refugees experience this situation far longer than 5 years, and it can last an estimated 26 years on average (UNHCR 2015). Additionally, according to the UNHCR (2009), 23 of the 32 protracted refugee situations have lasted for more than 20 years. Even so, in some cases protracted refugee situations continue for generations. 
Subsequently, many children are born and raised, and in some cases even become adults and elderly, while waiting for a durable solution regarding their uncertain future.

These refugees' lives 'may not be at risk, but their basic, rights [e.g. human rights and human dignity] and essential economic, social and psychological needs remain unfulfilled after years in exile' (UNHCR 2004, my italics). Additionally, refugees in this limbo situation are 'often unable to break free from enforced reliance on external assistance' (ibid., my italics), which continues to harm their bodily vulnerability.

As particularly vulnerable, children experiencing protracted refugee situations fall out of time by being mis-recognized through lacking love, respect and esteem, as well as self-confidence, self-respect and self-esteem. Accordingly, while living in a limbo situation, it is highly challenging to restore normalcy, stability, predictability and resilience, and hence avoid becoming, inter alia, refugee patients.

\section{Time as a Normative Resource}

Time, as well as falling out of time, is an existential matter if one's childhood is put on hold in terms of being excluded from a normal, stable and predictable lifecycle. To avoid this fate thus involves being recognized regarding everyday life routines (e.g. caring, eating, playing).

What Arendt $(1958$, p. 8$)$ conceptualizes as the human condition of natality-namely, temporality in terms of, for example, birth, life-course, action-considers time as existential; namely, a given and non-optional condition of human existence. Given that every human is ontologically a temporal being (Horst and Lysaker 2020). Although Arendt connects time to the human condition of mortality, being temporal also denotes unexpected and unpredicted action and interaction. Hence, temporality not only produces an inherent existential vulnerability of fragility or even mortality, but also generates what Arendt describes as the hopes and miracles of 'new beginnings' (Arendt 1958, pp. 9, 246-247) in capacity of thinking, judging and acting within spaces of appearance (ibid., pp. 5, 7, 198-199). Thus, prior to the human condition of plurality, meaning the diversity of unique identities, we must recognize each human's temporally preconditioned existence. This is partly what is at stake if someone, such as particularly vulnerable child refugees, falls out of time. 


\section{Time as a Scarce Good}

Humans as temporal beings infers that time is a scarce good, too. This is due to the ontological fact that we have more or less of it, and sometimes we have very little, almost no, time. Moreover, since our temporally preconditioned life course can be over any minute, this turns humans into a particularly vulnerable creature. Therefore, to have one's years with human dignity and life quality reduced-for instance, due to prolonged waiting - is both psychologically and relationally harmful.

Today, according to the UN's World Population Prospects 2015 Revision, the global average life expectancy at birth is around 71.5 years across gender. Nonetheless, humans' existential life graph and time as a scarce good demonstrate that not every individual has the opportunity to conduct their life in accordance with this average; that is, in line with time as a normative resource. Rather, a long, healthy life with quality and dignity can suddenly-such as when Goli risks his life to return to Norway while experiencing prolonged waiting - be undermined and eventually over.

This existential account of time resonates with Nussbaum's concept of human capabilities, which refers to 'what people are actually able to do and to be' (Nussbaum 2006, p. 70). The first, and most basic, capability is 'life' itself: 'Being able to live to the end of a human life of normal length [i.e. average life expectancy]; not dying prematurely, or before one's life is so reduced as to be not worth living' (Nussbaum 2006, p. 76, my italics). Furthermore, Nussbaum talks about 'functioning': '[capabilities] [...] use[...] the idea of a threshold level of each capability' (ibid., p. 71, original italics), 'beneath which it is held that truly human functioning is not available' (ibid., my italics). Accordingly, to live one's life in harmony with capabilities and functionally, each human being should be able to live to the end of a human life of average expectancy.

\section{WAiting Guarantee}

To find ways in which to avoid prolonged waiting in the case of Husein, Goli and other particularly vulnerable child refugees, we need to explore how ethically to limit such long-term limbo situations, too. 


\section{Ethics of the Temporary}

In light of an ethics of the temporary, which I relate to my own moral principle of a waiting guarantee, the problem of prolonged waiting is described as follows: 'far from being temporary, [forced] displacement [e.g. child refugees] ought to be rigorous ethical consideration'. Thus, we have to take a closer look at the 'the moral dimension of how [forced] displaced are treated between the time of their exile and when [if ever] they are finally able to find a permanent durable solution' (Parekh 2017, p. 3, my italics).

Along these lines, there are at least two reasons why the global situation of prolonged waiting should be criticized. First, empirically, ' $[\mathrm{t}]$ his period of time [e.g. prolonged waiting time or protracted refugee situation] is ever growing, and more and more people spend their lives' in such a situation (Parekh 2017, p. 3, my italics). The UNHCR (2015) documents that the global number of forced displaced people had reached 65.3 million. Here, more than $50 \%$ - that is, over 32 million-are children. Simultaneously, forced displaced minors are particularly vulnerable. Consequently, forced displacement is viewed by the UNHCR as one of the major humanitarian and developmental problems facing the world today. Relatedly, the UNHCR defines around 12 million out of the total of 65 million (i.e. nearly $20 \%$ ) as existing in protracted refugee situations.

Second, normatively, '[f]or the vast majority of people, [...] a [prolonged waiting] time [is] characterized by confinement and human rights violations' (Parekh 2017, p. 3, my italics). Accordingly, to the extent which human rights' moral core is the recognition of persons' inherent dignity (Habermas 2010), these human rights violations simultaneously disrespect their dignity. Against this backdrop, related to, for instance, refugee patients, it can be further claimed that prolonged waiting 'should [morally] not be the accepted norm'. Instead, child refugees and others subjected to forced displacement ought to be morally treated 'as fully human and with [morally] dignity' (ibid., my italics).

An adequate way in which to avoid child refugees' prolonged waiting, then, entails 'a morally acceptable way to house refugees [e.g. child refugees] and allow them to live with [inherent moral] dignity [even] while they are waiting to be resettled or to return to their home countries' (ibid., p. 137, my italics). Consequently, existing in a particular vulnerable life situation, which is exactly what child migrants such as Husein 
and Goli do, this should be taken into closer consideration. If so, accepting the mis-recognition of this groups' particular embodied vulnerability equals morally ignoring these refugees' very human condition as temporal beings, on the basis of which they belong to humanity and thus should have their dignity recognized.

\section{Embodied Human Dignity}

Dignity seems to be the overarching theme of Nowhere Home. During the documentary, Olin states that 'every human being must be a goal in itself'. However, Goli and other child migrants have their dignity misrecognized and apparently have no hope of regaining it.

To support Olin's claim, we thus have to address the concept of human dignity in a relevant manner, since this is the moral threshold level above which this group of refugees should live, even if-or, exactly when-they are exposed to prolonged waiting. Here, in line with Nussbaum's picture of human capabilities, inherent dignity can be approached from exactly the perspective of a moral threshold. What Nussbaum describes as 'life' itself, and the way in which it resonates with the Arendtian term 'natality', serves as an existential precondition for all the other capabilities: without existence in terms of human life in the first place, we cannot develop ourselves along the lines of the other capabilities (bodily health, senses, imagination, thought, emotions, practical reason, affiliation and so on).

Furthermore, this threshold identifies the fundamental requirements for living 'a life worthy of human dignity' (Nussbaum 2006, p. 70), which implies a 'fully human living' (ibid., p. 279) throughout a person's entire lifespan. To exist beneath this level, then, suggests that humans' embodied dignity is mis-recognized concerning the basic need for recognition in terms of love, respect and esteem, as well as positive self-development regarding self-confidence, self-respect and self-esteem (Honneth 1995).

One way in which my ethics of waiting can be normatively justified is to reject all prolonged waiting that exceeds the UNHCR's limit of 5 years of protracted refugee situations. Moreover, in accordance with the Arendtian idea of time as a human condition, as well as a normative resource and a scarce good, it can be argued that, as soon as the capability to live one's lifespan in accordance with one's inherent dignity and human rights, as well as bodily health and life quality (Turner 2006, p. 25) is undermined due to prolonged waiting, this situation is morally unacceptable. 
In Nussbaum, dignity is related precisely to both humans' temporality and embodiment. Temporally, since our capabilities are grounded in the very basic one, 'life' itself, it follows that the other capabilities should existentially and morally protect the ability to live to the end of a normal human lifespan. Moreover, to the extent to which this basic capability of life itself serves as the moral basis on which one should be able to live a life worthy of human dignity, the other capabilities should be achieved for 'each and every person, treating each as an end and none as a mere tool of the ends of others'. Hence, to have one's life course put on hold-as in the case of particularly vulnerable child refugees' prolonged waiting-is a way in which to have one's ontologically grounded and bodily appearing capability of life, and thus one's inherent dignity, mis-recognized. To Nussbaum, therefore, the very basic capability of life itself establishes 'a bare minimum of what respect for human dignity requires' (Nussbaum 2006, p. 70, my italics; see pp. 74, 180, 274, 278). In short, it expresses the moral grounding of humans' temporal life worthy of dignity.

Regarding embodiment, Nussbaum holds that the inherent moral worth of each person is primarily grounded in given and shared bodily ways in which humans exist and thus should be protected by others. Accordingly, dignity is something that 'inheres in the animal body' (Nussbaum 2006, p. 87) and 'bodily need[s]', including the need for recognition as care (ibid., p. 160). This central role of the body is also visible with regard to several other capabilities that safeguard 'truly human' life, such as 'bodily health' and 'bodily integrity' (ibid., p. 76). Here, the human body enables the realization of these capabilities through such capacities as the sense apparatus, the nervous system and our emotional life.

Nussbaum also argues that humans' inner worth 'could not be posed by a being who was not mortal and vulnerable' (Nussbaum 2006, p. 132, my italics; see pp. 87-88). Against this background, she argues that 'bodily need, including the need for care, is a feature of both of our rationality and our sociability' (ibid., p. 160, my italics). To care for others not only presupposes our own emotional and sensual empathy, but also that others are receptive addressees regarding such recognitive caregiving.

This idea of dignity is explicitly related to children, which can be linked to the issue of child refugees. To live a dignified life indicates to Nussbaum that others should treat each person through '[g]ood care'. This denotes that due to their 'acute or asymmetrical dependency' and 'primary needs', to respect children's dignity requires a special 'focus[...] on [the] support for capabilities of life, health, and bodily integrity' (Nussbaum 2006, 
p. 168). Hence, I not only take humans in general, but also, particularly, vulnerable child refugees as a group that requires special protection in light of the capabilities. Capability-based needs should, then, be normatively justified as children's 'special priority'. Such a moral priority, echoing the UNHCR's account of child refugees as particularly vulnerable, is based on what Nussbaum describes as 'the special pulnerability of children' (Dixon and Nussbaum 2012, p. 549, my italics; see Benporath 2003; Mullin 2014; Macleod 2017; Schweiger and Graf 2017).

Accordingly, she introduces a 'vulnerability principle', which holds that 'an important component to [the capabilities approach] [...] [is that] it recognizes human frailty and vulnerability as central parts of the [Arendtian] buman condition for adults as well as for children' (Dixon and Nussbaum 2012 , p. 584 , my italics). So, children's special vulnerability regarding, for instance, physical, emotional and cognitive maturity through recognitive and hence positive, undistorted self-development, can be safeguarded to a greater extent than is currently the case (ibid., p. 574). If so, the transnational situation of child refugees-particularly their prolonged waiting — would most certainly be improved.

\section{Towards a Waiting Guarantee}

The ethical guideline I wish to propose can be stated thus: it is morally unacceptable if prolonged waiting puts child refugees' childhood on hold. An important aspect of this waiting guarantee is the way in which it requires being more aware concerning the difference between 'misrecognition' and 'non-recognition' (Lysaker 2013). Recognition as love, respect and esteem are basic bodily and relational needs that are ontologically shared by all humans. However, in cases in which people lack such recognition, it occurs in at least two ways. With mis-recognition, I mean when humans in general, and child refugees in particular, are capable of struggling to regain their recognition after being humiliated. Hence, such cases are 'ordinary' in the sense that the very struggle may take a while to succeed, but without lasting too long as for the mis-recognized person to yet again being recognized.

Non-recognition, however, undermines even the person's very capacity to struggle for recognition after being mis-recognized in terms of traumatization or dehumanization. For instance, in cases in which child refugees are exposed to prolonged waiting, as well as traumatization before, under and/or after the flight, the implication of this can be that the children's 
prolonged waiting is even further prolonged due to the traumatizations as non-recognition. Then, these two forms of recognitive negation are ways in which to identify the moral threshold level in Nussbaum, beneath which the dignity of child refugees is turned into the situations in which these children cannot regain their recognized life form due to severe bodily health issues stemming from their prolonged waiting.

To prevent not only what I describe as mis-recognition, but also nonrecognition, it is relevant to relate Nussbaum's 'vulnerability principle' in the case of children-including child refugees-to the UN 1989 Child Convention. Here, Article 3 declares the following moral principle: 'In all actions concerning children, whether undertaken by public or private social welfare institutions, courts of law, administrative authorities or legislative bodies, the best interests of the child shall be a primary consideration' (UN 1989, my italics). So, if the best interests of the child shall be safeguarded, particularly the vulnerable group of child refugees should not be exposed to prolonged waiting in terms of non-recognition, including its costs concerning reduced bodily health and life quality, as well as violated inherent dignity and human rights.

\section{CONCLUSION}

In Nowhere Home, we are told the life histories of child migrants such as Husein, Hassan and Goli. Starting from brief examples from the documentary, I have explored the dynamics between vulnerability, child refugees and prolonged waiting. I have underscored how various exclusion mechanisms mis-recognize this group of irregular migrants' inherent dignity, bodily health, life quality and human rights.

Accordingly, particularly vulnerable child refugees should not have their childhood put on hold due to prolonged waiting. Instead, the ethical demand of Olin's documentary, as I see it, concerns recognizing child refugees' basic capabilities to live above the threshold level concerning the vulnerable and injurable nature of their embodied dignity.

Acknowledgements I would like to thank Serena Parekh, John Christman, Synnøve Bendixsen, Line Indrevoll Stänicke, Zemir Popovac and Hilde Lidén, as well as the editors for their comments. Earlier versions of this chapter were presented in 2018 at the conferences Philosophy and Social Science in Prague, and Refugees and Minority Rights: Acceptable and Unacceptable Criteria for Accepting/Rejecting Refugees in a Non-Ideal World at the University of Tromsø; as 
well as at the workshop Reason and Affect in Divided Societies: The Nordic Case at the Uppsala University, and in 2017 at the Centre for Women's and Gender Research at the University of Bergen. I would like to thank the audiences at these events for their feedback. The chapter is published as part of the research project WAIT (Waiting for an Uncertain Future: The Temporalities of Irregular Migration), which is funded by the Research Council of Norway.

\section{REFERENCES}

Anda, R. F., Felitti, V. J., Bremner, J. D., Walker, J. D., Whitfield, C., Perry, B. D., et al. (2006). The enduring effects of abuse and related adverse experiences in childhood. European Archives of Psychiatry and Clinical Neuroscience, 256(3), 174-186.

Anderson, J. (2017). Ordinary vulnerability, institutional androgyny, and gender justice. In C. Straehle (Ed.), Vulnerability, Autonomy, and Applied Ethics. London: Routledge.

Anderson, J., \& Honneth, A. (2005). Autonomy, vulnerability, recognition, and justice. In J. Christman \& J. Anderson (Eds.), Autonomy and the Challenges to Liberalism. Cambridge: Cambridge University Press.

Arendt, H. (1958). The Human Condition. Chicago: University of Chicago Press.

Benporath, S. R. (2003). Autonomy and vulnerability: On just relations between adults and children. Journal of Philosophy of Education, 37(1), 127-145.

Bhabha, J. (2016). Child Migration and Human Rights in a Global Age. Princeton: Princeton University Press.

Butler, J. (2004). Precarious Life: The Power of Mourning and Violence. London: Verso.

Butler, J. (2010). Frames of War: When Is Life Grievable? London: Verso.

Carswell, K., Blackburn, P., \& Barker, C. (2009). The relationship between trauma, post-migration problems and the psychological well-being of refugees and asylum seekers. International Journal of Social Psychiatry, 57(2), 107-119.

Cassidy, J., \& Mohr, J. J. (2001). Unsolvable fear, trauma, and psychopathology: Theory, research, and clinical considerations related to disorganized attachment across the life span. Clinical Psychology, 8(3), 275-298.

Crock, M., \& Bhabha, J. (Eds.). (2007). Seeking Asylum Alone. Sydney: Themis Press.

Dixon, R., \& Nussbaum, M. C. (2012). Children's rights and a capabilities approach: The question of special priority. Cornell Law Review, 97(3), 549-594. 
Fazel, M., Reed, R. V., Panter-Brick, C., \& Stein, A. (2012). Mental health of displaced and refugee children resettled in high income countries. The Lancet, 379(9812), 266-282.

Ferrarese, E. (2017). The vulnerable and the political: On the seeming impossibility of thinking vulnerability and the political together and its consequences. In E. Ferrarese (Ed.), The Politics of Vulnerability. London: Routledge.

Ferrarese, E. (2018). Vulnerability and Critical Theory. Leiden: Brill.

Fineman, M. A. (2008). The vulnerable subject: Anchoring equality in the human condition. Yale Journal of Law and Feminism, 20(1), 1-23.

Fineman, M. A. (2010). The vulnerable subject and the responsive state. Emory Law Journal, 60(2), 251-275.

Fineman, M. A. (2013). Equality, autonomy, and the vulnerable subject in law and politics. In M. A. Fineman \& A. Grear (Eds.), Vulnerability: Reflections on a New Ethical Foundation for Law and Politics. London: Routledge.

Gilson, E. (2013). The Ethics of Vulnerability: A Feminist Analysis of Social Life and Practice. London: Routledge.

Graf, G., \& Schweiger, G. (2017). Ethics and the Endangerment of Children's Bodies. Basingstoke: Palgrave Macmillan.

Habermas, J. (2010). The concept of human dignity and the realistic utopia of human rights. Metaphilosophy, 41(4), 464-480.

Hagestad, G. O. (1996). On-time, off-time, out of time? Reflections on continuity and discontinuity from an illness process. In V. L. Bengtson (Ed.), Adulthood and Aging. New York: Springer.

Hagestad, G. O., \& Dykstra, P. (2016). Structuration of the life course: Some neglected aspects. In M. J. Shanahan, J. T. Mortimer, \& M. Kirkpatrick Johnson et al. (Eds.), Handbook of the Life Course (Vol. 2). New York: Springer.

Honneth, A. (1995). The Struggle for Recognition: The Moral Grammar of Social Conflicts. Cambridge: MIT Press.

Honneth, A. (2001). Recognition or redistribution? Changing perspectives on the moral order of society. Theory, Culture, and Society, 18(2-3), 43-55.

Horst, C., \& Lysaker, O. (2020, forthcoming). Miracles in Dark Times: Hannah Arendt and the Refugee as 'Vanguard'. Journal of Refugee Studies.

Jakobsen, M., Meyer DeMott, M. A., Wentzel-Larsen, T., \& Heir, T. (2017). The impact of the asylum process on mental health: A longitudinal study of unaccompanied refugee minors in Norway. British Medical Journal Open, $7(6), 1-8$.

Jensen, T. K., Fjermestad, K. W., Granly, L., \& Wilhelmsen, N. H. (2015). Stressful life experiences and mental health problems among unaccompanied asylum-seeking children. Clinical Child Psychology and Psychiatry, 20(1), 106-116.

Kulu-Glasgow, I., Smit, M., \& Sirkeci, I. (Eds.). (2019). Unaccompanied Children: From Migration to Integration. London: Transnational Press. 
Li, S. S., Liddell, B. J., \& Nickerson, A. (2016). The relationship between post-migration stress and psychological disorders in refugees and asylum seekers. Disaster Psychiatry, 18(82), 81-90.

Lysaker, O. (2013). Menneskeverdets politikk: Anerkjennelse av kroppslig krenkbarhet. Oslo: Abstrakt.

Lysaker, O. (2015). Å leve et menneskeverdig liv: Martha Nussbaums globale helseetikk. Nordic Journal of Applied Ethics, 9(2), 53-70.

Mackenzie, C. (2014). The importance of relational autonomy and capabilities for an ethics of vulnerability. In C. Mackenzie, W. Rogers, \& S. Dodds (Eds.), Vulnerability: New Essays in Ethics and Feminist Philosophy. Oxford: Oxford University Press.

Mackenzie, C. (2017). Vulnerability, needs, and moral obligation. In C. Straehle (Ed.), Vulnerability, Autonomy, and Applied Ethics. London: Routledge.

Mackenzie, C., et al. (2014). Introduction: What is vulnerability and why does it matter for moral theory? In C. Mackenzie, W. Rogers, \& S. Dodds (Eds.), Vulnerability: New Essays in Ethics and Feminist Philosophy. Oxford: Oxford University Press.

Macleod, C. (2017). Doctrinal vulnerability and the authority of children's voices. In C. Straehle (Ed.), Vulnerability, Autonomy and Applied Ethics. New York: Routledge.

Miller, K. E., \& Rasmussen, A. (2010). War exposure, daily stressors, and mental health in conflict and post-conflict settings: Bridging the divide between trauma-focused and psychosocial frameworks. Social Science and Medicine, $70(1), 7-16$.

Mullin, A. (2014). Children, vulnerability, and emotional harm. In C. Mackenzie, W. Rogers, \& S. Dodds (Eds.), Vulnerability: New Essays in Ethics and Feminist Philosophy. Oxford: Oxford University Press.

Nussbaum, M. C. (2004). Hiding from Humanity: Disgust, Shame, and the Law. Princeton: Princeton University Press.

Nussbaum, M. C. (2006). Frontiers of Justice: Disability, Nationality, Species Membership. Cambridge, MA: Harvard University Press.

Nussbaum, M. C. (2013). Political Emotions: Why Love Matters for Justice. Cambridge, MA: Belknap Press.

Parekh, S. (2017). Refugees and the Ethics of Forced Displacement. New York: Routledge.

Petherbridge, D. (2016). What's critical about vulnerability? Rethinking interdependence, recognition, and power. Hypatia, 31(3), 589-604.

Schweiger, G., \& Graf, G. (2017). Ethics and the dynamic of vulnerability of children. Les Ateliers de L'éthique, 12(2-3), 243-261.

Settersten, R. A., Jr., \& Hagestad, G. O. (1996). What's the latest? Cultural age deadlines for family transitions. The Gerontologist, 36(2), 178-188. 
Silas, W. A. (2018). A desired composition: Regulating vulnerability through immigration law. In M. A. Fineman \& J. W. Fineman (Eds.), Vulnerability and the Legal Organization of Work. New York: Routledge.

Silove, D., Steel, Z., Susljik, I., Frommer, N., Loneragan, C., Chey, T., et al. (2007). The impact of the refugee decision on the trajectory of ptsd, anxiety, and depressive symptoms among asylum seekers. American Journal of Disaster Medicine, 2(6), 321-329.

Sourander, A. (1998). Behaviour problems and traumatic events of unaccompanied refugee minors. Child Abuse and Neglect, 22(7), 719-727.

Turner, B. S. (2006). Vulnerability and Human Rights. University Park, PA: Penn State University Press.

UN. (1989). The Convention on the Rights of the Child. http://www.ohchr.org/ EN/ProfessionalInterest/Pages/CRC.aspx. Accessed 18 January 2019.

UNHCR. (1951). The 1951 Convention and Its 1967 Protocol: Relating to the Status of Refugees. https://www.unhcr.org/4ec262df9.pdf. Accessed 31 May 2019.

UNHCR. (1998). Refugee Children: Guidelines on Protection and Care. http:// www.unhcr.org/3b84c6c67.pdf. Accessed 18 January 2019.

UNHCR. (1999). Protecting Refugees: A Field Guide for NGOs. UNHCR: Geneva. https://www.unhcr.org/3d4a5b634.pdf. Accessed 31 May 2019.

UNHCR. (2004). Protracted Refugee Situations. Standing Committee, 30th Meeting, 10 June. https://www.unhcr.org/40c982172.pdf. Accessed 31 May 2019.

UNHCR. (2009). Conclusion on Protracted Refugee Situations, No. 109 (LXI). Executive Committee 61st Session. https://www.unhcr.org/excom/exconc/ 4b332bca9/conclusion-protracted-refugee-situations.html. Accessed 31 May 2019.

UNHCR. (2015). UNHCR Global Trends 2015. https://www.unhcr.org/ 576408cd7.pdf. Accessed 18 February 2020.

UNHCR. (2016). Caring for the Vulnerable. Helping Those with Special Needs. http://www.unhcr.org/ceu/96-enwhat-we-docaring-for-the-vulnerable-html. html. Accessed 18 January 2019.

Varvin, S. (2008). Flyktningpasienten. Oslo: Universitetsforlaget. 
Open Access This chapter is licensed under the terms of the Creative Commons Attribution 4.0 International License (http://creativecommons.org/licenses/ by $/ 4.0 /$ ), which permits use, sharing, adaptation, distribution and reproduction in any medium or format, as long as you give appropriate credit to the original author(s) and the source, provide a link to the Creative Commons license and indicate if changes were made.

The images or other third party material in this chapter are included in the chapter's Creative Commons license, unless indicated otherwise in a credit line to the material. If material is not included in the chapter's Creative Commons license and your intended use is not permitted by statutory regulation or exceeds the permitted use, you will need to obtain permission directly from the copyright holder.

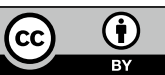

